\title{
Differentiation of a Fusicoccum sp. Causing Panicle and Shoot Blight on California Pistachio Trees from Botryosphaeria dothidea
}

\author{
Denise R. Smith, Department of Plant Pathology, University of Wisconsin, Madison 53706; Themis J. \\ Michailides, University of California, Davis, and Kearney Agricultural Center, Parlier, CA 93648; and Glen R. \\ Stanosz, Department of Plant Pathology, University of Wisconsin
}

\begin{abstract}
Smith, D. R., Michailides, T. J., and Stanosz, G. R. 2001. Differentiation of a Fusicoccum sp. causing panicle and shoot blight on California pistachio trees from Botryosphaeria dothidea. Plant Dis. 85:1235-1240.

A panicle and shoot blight disease of pistachio trees in California is caused by a fungus previously identified as the anamorph of Botryosphaeria dothidea. We have compared random amplified polymorphic DNA (RAPD) markers, nuclear rDNA internal transcribed spacer (ITS) region sequences, and conidium morphology of 15 isolates of the pistachio Fusicoccum to those of well-characterized isolates of $B$. dothidea, B. ribis, and $F$. luteum. Cluster analysis of RAPD markers separated the pistachio Fusicoccum isolates from $B$. dothidea, as did parsimony analysis of the ITS region sequences. Conidium size and shape were similar to those of $B$. ribis (Fusicoccum sp.) and F. luteum, but distinguishable from those of $F$. aesculi (the anamorph of $B$. dothidea). We conclude that the fungus causing panicle and shoot blight of pistachio is distinguishable from $B$. dothidea and is part of a complex containing B. ribis, F. luteum, and other fungi with Fusicoccum anamorphs.
\end{abstract}

Additional keywords: Botryosphaeria ribis, Fusicoccum aesculi, Fusicoccum luteum, Pistacia vera

A disease characterized by panicle and shoot blight was observed on pistachio (Pistacia vera L. cv. Kerman) in Butte County, CA in 1984 and later in other parts of the state (17). A pycnidial fungus consistently was isolated from symptomatic plant parts (12). Koch's postulates were completed with production of symptoms on pistachio similar to those observed in the field (12). Subsequent spread of the pathogen throughout California and the severity of epidemics which substantially reduce nut quality and yield have led to consideration of this disease as the greatest threat to the California pistachio industry $(11,13)$.

The pathogen that causes this disease was referred to by Michailides (12) as Botryosphaeria dothidea. He reported that isolates of the panicle and shoot blight pathogen were consistent with the description of the pycnidial stage of Botryosphaeria ribis $(12,15)$, which had previously been placed in synonymy with $B$. dothidea (1). Identification of the pistachio panicle and shoot blight pathogen as $B$. dothidea also was based on comparison of morpho-

Corresponding author: D. R. Smith

dzs@plantpath.wisc.edu

Accepted for publication 8 August 2001.

Publication no. D-2001-1008-01R

(C) 2001 The American Phytopathological Society logical and cultural characteristics of several isolates to a fungus identified as $B$. dothidea that causes a bandlike canker of almonds and an isolate of $B$. dothidea from peach $(2,8,12)$. The anamorphs of both the almond bandlike canker pathogen and the pistachio panicle and shoot blight pathohave been referred to as Dothiorella spp. $(8,12)$. According to Sutton, however, the anamorph of $B$. dothidea (which produces hyaline conidia) is Fusicoccum aesculi (28). In addition, the name Dothiorella now appears to be inappropriate because it recently was synonymized with Diplodia, a genus reserved for fungi with pigmented conidia $(6,7)$.

Identification and classification of Botryosphaeria spp. and associated anamorphic fungi can be difficult. Morphological differences, especially among Fusicoccum anamorphs, may not be distinctive, and the taxonomic and pathological history of many of these fungi is muddled. For examtheir decision, von Arx and Müller (1) placed a number of Botryosphaeria spp. (and associated anamorphic fungi) in synonymy. Other authors have not accepted the synonymy of taxa such as B. ribis with $B$. dothidea, and the former name continues to be used $(9,15,16)$. Another very similar fungus in this group is $F$. luteum, associated with kiwifruit rot (14), but also collected from a variety of native plants in gen, which produce hyaline conidia, also ple, although not describing any basis for Australia and pistachio in Italy (21). Re- cently, studies of both morphological characteristics and molecular markers have allowed differentiation of $B$. dothidea and its anamorph from a complex containing $B$. ribis, $F$. luteum, and other fungi with Fusicoccum anamorphs $(21,32)$.

During preliminary examination, differences were noted among random amplified polymorphic DNA (RAPD) markers from the pistachio panicle and shoot blight pathogen and those from isolates of $B$. dothidea. Correct identification is important for both disease management and further research on the pistachio panicle and shoot blight pathogen; therefore, studies were undertaken to compare it to previously characterized isolates of $B$. dothidea, $B$. ribis, and F. luteum. Differences among RAPD markers and nuclear ribosomal internal transcribed spacer (ITS) sequences were analyzed and the sizes and shapes of conidia were compared.

\section{MATERIALS AND METHODS}

Fungal isolates. Isolates used in this study were purchased from culture collections or were obtained from symptomatic host material by the authors or cooperators (Table 1). The isolates of the pistachio panicle and shoot blight pathogen included five from each of three geographic areas of pistachio production in California. Four previously characterized isolates of Sphaeropsis sapinea RAPD marker group A (24) were included as an outgroup for comparison in both RAPD marker analyses and ITS sequence analysis (Table 1).

RAPD marker data. Data generated for the 15 isolates of the pistachio panicle and shoot blight pathogen were compared with existing data for representative isolates from a more comprehensive study of relationships among B. dothidea (94-104, 96-6, 96-15, 97-5, and 97-94), B. ribis (94-128, 94-131, 96-12, 96-187, and 97-113), and $F$. luteum (97-38, 97-40, 97-45, 97-78, and 97-88) (21). Procedures, materials, and equipment for genomic DNA extraction and amplification were similar to those previously described (20). Primers DS1 (5'-CTGCGACTGAATCTTGCAG) and DS13 (5'-GGTGCCTATAAACGCAACAGG), however, were used in place of DS2 and DS4. Eight 17- to 21-nt primers were used. DNA amplification took place in two steps, the first allowing low stringency annealing of primers $\left(40^{\circ} \mathrm{C}\right)$ and the second allowing high stringency annealing 
$\left(55^{\circ} \mathrm{C}\right)$. DNA fragments were separated on $0.7 \%$ agarose gels in Tris-boric acid-EDTA (TBE) buffer and photographed after staining with ethidium bromide. Each isolate usually was assayed three times by growing a culture, extracting DNA, amplifying the DNA with each primer, and separating the fragments. However, for a few isolateprimer combinations, only two assays were performed.

Each isolate was scored for the presence or absence of each amplification product. Only amplification products that were present throughout all repetitions for at least one isolate were included in the analysis. Because of the large diversity of fragments, Southern blots were not performed to test fragment homology.

Relationships among isolates were determined by calculation of Jaccard's similarity coefficient $\left(S_{\mathrm{J}}\right)$ for each pair of isolates. Jaccard's similarity coefficient is calculated by the formula described by Sneath and Sokal (22): $S_{\mathrm{J}}=a /(a+u)$, where $a$ is the number of matches of positive data points between two isolates and $u$ is the total number of fragments unique to each isolate. A phenogram was constructed after cluster analysis of the similarity coefficients by the unweighted pairgroup method using arithmetic averages (UPGMA; 22). These calculations were performed with the programs SIMQUAL and SAHN of the software package NTSYS-pc (ver. 2.0; Exeter Software, Setauket, NY).

ITS sequence data. Sequence data from the nuclear ribosome ITS and 5.8S gene were compared for selected isolates (Table 1). These included five isolates of the pistachio panicle and shoot blight pathogen (at least one from each major pistachioproducing area in California). Sequences of $B$. dothidea, B. ribis, and F. luteum isolates were obtained from GenBank or had been acquired during other recent investigations $(21,32)$. One isolate from $S$. sapinea RAPD marker group A was used as an outgroup.
For sequences acquired in this study, DNA was extracted using the same procedure as for RAPD markers. The ITS region was amplified using fungal universal primers ITS1 or ITS5 and ITS4 (31). Polymerase chain reaction (PCR) was performed in 100- $\mu$ l reactions consisting of 1 $\mathrm{U}$ of Taq DNA Polymerase, $1 \times$ buffer, 2.0 $\mathrm{mM} \mathrm{MgCl} 2,150 \mu \mathrm{M}$ each dNTP (all purchased from Promega Corp., Madison, WI), $2 \mu \mathrm{M}$ each primer (University of Wisconsin-Madison Biotechnology Center), and 2 to $10 \mathrm{ng}$ of DNA. Each reaction mixture was overlaid with mineral oil and the following temperature profile was used in a Perkin-Elmer Thermal Cycler 480 (Norwalk, CT): 1 cycle of $5 \mathrm{~min}$ at $95^{\circ} \mathrm{C}$; followed by 30 cycles of $1 \mathrm{~min}$ at $95^{\circ} \mathrm{C}, 1$ min at $60^{\circ} \mathrm{C}$, and $1 \mathrm{~min}$ at $72^{\circ} \mathrm{C}$; followed by 1 cycle of $5 \mathrm{~min}$ at $72^{\circ} \mathrm{C}$. Fragment sizes were determined on $0.7 \%$ agarose TBE gels. The fragments were purified using the QIAGEN QIAquick PCR Purification kit (QIAGEN Inc., Chatsworth,

Table 1. Isolates used to investigate relationships among pistachio Fusicoccum isolates and some other Botryosphaeria and Fusicoccum species

\begin{tabular}{|c|c|c|c|c|c|c|c|}
\hline $\mathbf{R A P D}^{\mathbf{w}}$ & Isolate & Host & Location & Collector & Other no. ${ }^{\mathrm{x}}$ & Acc. no. ${ }^{y}$ & References \\
\hline $\mathrm{Fp}$ & $99-6$ & Pistacia vera ${ }^{\mathrm{Z}}$ & Kern Co., CA & T. Michailides & $\ldots$ & $\ldots$ & $\ldots$ \\
\hline $\mathrm{Fp}$ & $99-7$ & P. vera & Kern Co., CA & T. Michailides & $\ldots$ & AF357535 & $\ldots$ \\
\hline $\mathrm{Fp}$ & $99-8$ & P. vera & Kern Co., CA & T. Michailides & $\ldots$ & AF357536 & $\ldots$ \\
\hline $\mathrm{Fp}$ & $99-9$ & P. vera & Kern Co., CA & T. Michailides & $\ldots$ & $\ldots$ & $\ldots$ \\
\hline $\mathrm{Fp}$ & $99-10$ & P. vera & Kern Co., CA & T. Michailides & $\ldots$ & $\ldots$ & $\ldots$ \\
\hline $\mathrm{Fp}$ & $99-11$ & P. vera & $\begin{array}{l}\text { Madera or Merced Co., } \\
\text { CA }\end{array}$ & T. Michailides & $\cdots$ & AF357537 & $\cdots$ \\
\hline $\mathrm{Fp}$ & $99-12$ & P. vera & $\begin{array}{l}\text { Madera or Merced Co., } \\
\text { CA }\end{array}$ & T. Michailides & $\ldots$ & $\cdots$ & $\cdots$ \\
\hline $\mathrm{Fp}$ & $99-13$ & P. vera & $\begin{array}{l}\text { Madera or Merced Co., } \\
\text { CA }\end{array}$ & T. Michailides & $\cdots$ & .. & $\ldots$ \\
\hline $\mathrm{Fp}$ & $99-14$ & P. vera & $\begin{array}{l}\text { Madera or Merced Co., } \\
\text { CA }\end{array}$ & T. Michailides & $\cdots$ & $\cdots$ & $\ldots$ \\
\hline $\mathrm{Fp}$ & $99-15$ & P. vera & $\begin{array}{l}\text { Madera or Merced Co., } \\
\text { CA }\end{array}$ & T. Michailides & $\ldots$ & AF357538 & $\cdots$ \\
\hline $\mathrm{Fp}$ & $99-16$ & P. vera & Butte or Glenn Co., CA & T. Michailides & $\ldots$ & AF357539 & $\ldots$ \\
\hline $\mathrm{Fp}$ & $99-17$ & P. vera & Butte or Glenn Co., CA & T. Michailides & $\ldots$ & $\ldots$ & $\ldots$ \\
\hline $\mathrm{Fp}$ & $99-18$ & P. vera & Butte or Glenn Co., CA & T. Michailides & $\ldots$ & $\ldots$ & $\ldots$ \\
\hline $\mathrm{Fp}$ & $99-19$ & P. vera & Butte or Glenn Co., CA & T. Michailides & $\ldots$ & $\ldots$ & $\ldots$ \\
\hline $\mathrm{Fp}$ & $99-20$ & P. vera & Butte or Glenn Co., CA & T. Michailides & $\ldots$ & $\ldots$ & \\
\hline $\mathrm{Bd}$ & 94-104 & Liquidambar styraciflua & South Carolina & R. Roncadori & B12 & $\ldots$ & 21 \\
\hline $\mathrm{Bd}$ & $96-6$ & Prunus persica & Georgia & P. L. Pusey & $\mathrm{Bd} 80,94.27$ & AF027748 & $9,21,32$ \\
\hline $\mathrm{Bd}$ & $96-15$ & Prunus persica & Japan & P. L. Pusey & $\mathrm{Bd} 73,94.26$ & AF027749 & 9,21 \\
\hline $\mathrm{Bd}$ & $97-5$ & Malus sp. & Wisconsin & P. McManus & & AF241173 & 4,21 \\
\hline $\mathrm{Bd}$ & $97-94$ & Populus nigra & New Zealand & G. Samuels & GJS 83-545, ATCC 58188 & AF241175 & $14,21,32$ \\
\hline $\mathrm{Br}$ & $94-128$ & $\begin{array}{l}\text { Melaleuca quinquener- } \\
\text { via }\end{array}$ & Florida & M. Rayachhetry & $\begin{array}{l}\text { M4, 94.09, 96-7, } \\
\text { DAOM 229436 }\end{array}$ & AF027743 & $9,16,21,32$ \\
\hline $\mathrm{Br}$ & $94-131$ & Rhizophora mangle & Florida & M. Rayachhetry & R7, 94.11, 96-8 & $\ldots$ & $9,16,21,32$ \\
\hline $\mathrm{Br}$ & $96-12$ & Malus sp. & Washington, D.C. & K. Jacobs & 93.42 & AF027741 & $9,21,32$ \\
\hline $\mathrm{Br}$ & $96-187$ & Ribes rubrum & Not known & N.E. Stevens & CBS 121.26 & AF241177 & 21,32 \\
\hline $\mathrm{Br}$ & $97-113$ & Rhus typhina & Wisconsin & D. R. Smith & $\ldots$ & AF241176 & 21,32 \\
\hline $\mathrm{Fl}$ & $97-38$ & Banksia caleyi & Australia & H. White & WA 6731 & $\ldots$ & 21 \\
\hline $\mathrm{Fl}$ & $97-40$ & B. caleyi & Australia & H. White & WA 6733 & AF241178 & 21,32 \\
\hline $\mathrm{Fl}$ & $97-45$ & Jacksonia horrida & Australia & H. White & WA 6738 & $\ldots$ & 21 \\
\hline $\mathrm{Fl}$ & $97-78$ & Pistacia sp. & Italy & L. Sparapano & $\ldots$ & AF293479 & 21 \\
\hline $\mathrm{Fl}$ & $97-88$ & Actinidia chinensis & New Zealand & G. Samuels & ATCC 58194, 93.52 & AF027745 & $9,14,21,32$ \\
\hline SsA & 239 & Pinus resinosa & Wisconsin & M. Palmer & $\ldots$ & $\ldots$ & 24 \\
\hline SsA & 411 & P. resinosa & Minnesota & M. Palmer & DAOM 229440 & AF243409 & 24 \\
\hline SsA & $92-19$ & P. resinosa & Wisconsin & G. R. Stanosz & $\ldots$ & $\ldots$ & 24 \\
\hline SsA & $92-66$ & P. sylvestris & Michigan & G. R. Stanosz & $\ldots$ & $\ldots$ & 24 \\
\hline
\end{tabular}

${ }^{\mathrm{w}}$ Random amplified polymorphic DNA (RAPD) marker group as characterized in this study or previously determined (21); Bd = Botryosphaeria dothidea,

$\mathrm{Br}=$ B. ribis, $\mathrm{Fp}=$ pistachio Fusicoccum, $\mathrm{Fl}=$ Fusicoccum luteum, and $\mathrm{SsA}=$ Sphaeropsis sapinea $\mathrm{RAPD}$ marker group A.

${ }^{x}$ Isolate numbers assigned by collectors or culture collections.

y GenBank accession numbers for isolates from which an internal transcribed spacer region sequence was obtained.

${ }^{\mathrm{z}}$ P. vera cv. Kerman. 
CA), labeled with the ABI Prism BigDye Terminator Cycle Sequencing Kit (PE Biosystems, Foster City, CA), then sequenced by the University of WisconsinMadison Biotechnology Center on a PE Biosystems 377XL automated sequencer.

The complete sequences for the ITS region (partial 18S, ITS1, 5.8S gene, ITS2, and partial $28 \mathrm{~S}$ sequences) were aligned using ClustalX 1.64b (30) with gap penalty $=25$ and gap extension penalty $=5$. The alignment was manually adjusted in the data editor of PAUP* (29). Phylogenetic relationships were determined using the same program. A heuristic search with tree bisection-reconnection and random addition of sequences was performed. Nucleotide substitutions were unordered, but transversions were more heavily penalized (weight $=5$ ) than transitions (weight $=1$ ). Alignment gaps were treated as missing data. The sequence from $S$. sapinea isolate 411 was used as an outgroup. To determine the support for each clade, bootstrap analysis was performed with 1,000 replicates.

Conidium morphology. Sizes and shapes of conidia were compared using methods that previously permitted differentiation of the conidia of $B$. dothidea from those of some other fungi with Fusicoccum anamorphs (21). Isolates of the pistachio panicle and shoot blight pathogen (99-7, 99-12, and 99-13), B. dothidea (96-6, 9614, 97-5, and 97-114), B. ribis (94-131), and F. luteum (96-130 and 97-45) (Table 1) were grown on Difco potato dextrose agar at $12^{\circ} \mathrm{C}$ with $12 \mathrm{~h}$ of light (fluorescent and black lights) per day. After 42 days of incubation, conidia from squash mounts of pycnidia were observed by light and differential interference contrast microscopy and photographed. Three mature pycnidia (based on the predominance of apparently fully developed spores and scarcity of smaller, possibly less developed spores) were selected for each isolate after 52 or 53 days of incubation. Lengths and widths of 20 conidia from each pycnidium were measured in water with a light microscope with an ocular micrometer. Analyses of variance (ANOVA) and calculations of Fisher's protected least significant difference (LSD) for length, width, and length/width were performed using Minitab for Windows (ver. 12; Minitab Inc., State College, PA).

\section{RESULTS}

RAPD markers. Eight RAPD primers produced 90 scorable fragments. Most fragments were between 300 and 1,000 bp long. Seven fragments were unique to isolates of the pistachio panicle and shoot blight pathogen (subsequently referred to as the pistachio Fusicoccum). Only one fragment was shared between the pistachio Fusicoccum isolates and the B. dothidea isolates, one other fragment was shared between the pistachio Fusicoccum isolates and the $B$. ribis isolates, and yet another fragment was shared between the pistachio Fusicoccum isolates and the $F$. luteum isolates. Three fragments were shared among the pistachio Fusicoccum isolates, the $B$. ribis isolates, and the F. luteum isolates. Two fragments were shared among the pistachio Fusicoccum isolates, the $B$. dothidea isolates, and the $B$. ribis isolates.

The phenogram generated by cluster analysis placed the pistachio Fusicoccum isolates in a group separate from the other species (Fig. 1). The Jaccard's coefficients calculated for RAPD marker data indicated at least $68 \%$ similarity among the isolates in this pistachio Fusicoccum group. Similarity between this group and the group composed of $B$. dothidea isolates was only $12 \%$. The pistachio Fusicoccum group was only $7 \%$ similar to the $F$. luteum group and $5 \%$ similar to the B. ribis group.

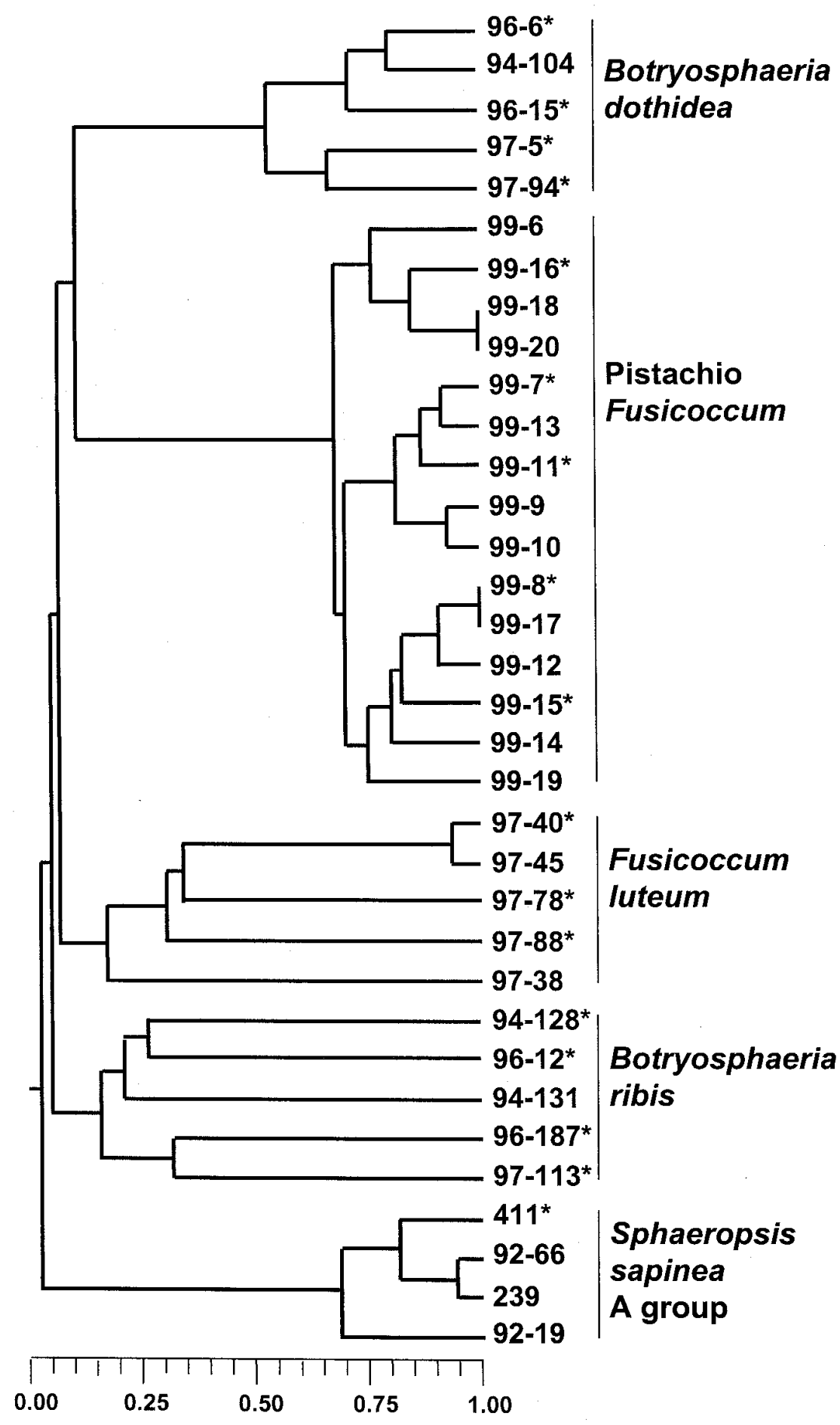

Fig. 1. Phenogram produced by unweighted pair-group method using arithmetic averages (UPGMA) analysis of similarity coefficients from random amplified polymorphic DNA (RAPD) marker data. Asterisk $(*)$ denotes isolates for which internal transcribed spacer region DNA sequence was analyzed. Scale represents percent similarity $(1.00=100 \%)$. 
ITS sequence comparisons. The ITS sequence alignment indicated that the pistachio Fusicoccum isolates differed from their closest relative, $F$. luteum, by only five nucleotides in ITS1 and three nucleotides in ITS2. In contrast, the pistachio Fusicoccum isolates differed from the $B$. dothidea isolates by 14 nucleotides in ITS1 and 17 nucleotides in ITS2. Maximum parsimony analysis produced a single most parsimonious tree of 102 steps (consistency index $=0.8824$ and retention in$\operatorname{dex}=0.9344)$. The $B$. dothidea isolates

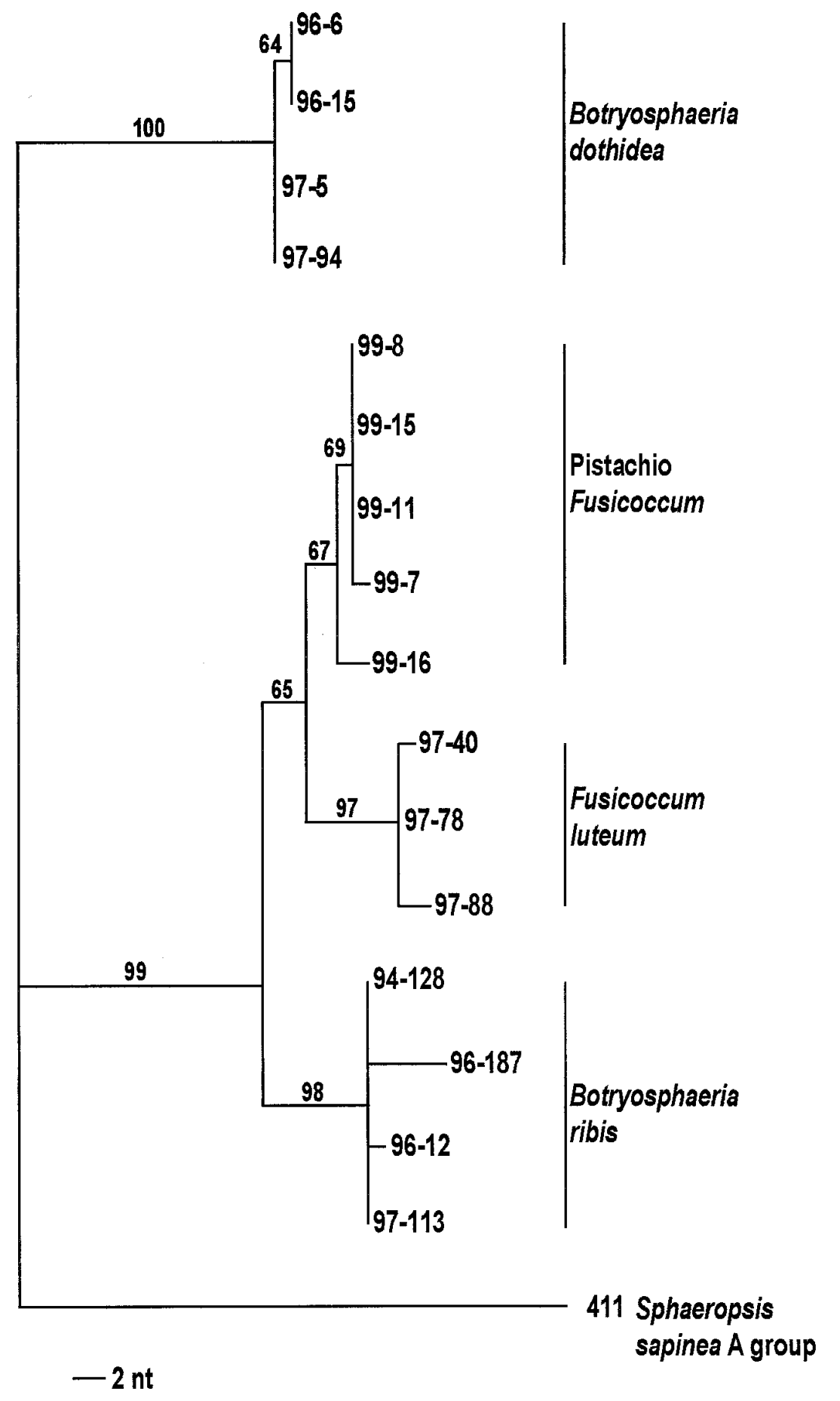

Fig. 2. Phylogram produced by bootstrap analysis of internal transcribed spacer region DNA sequences. Numbers above lines indicate bootstrap support. were distinctly separate from the pistachio Fusicoccum isolates and the other groups with 100\% bootstrap support (Fig. 2). Bootstrap analysis also very strongly supported the grouping of the pistachio Fusicoccum isolates with $F$. luteum isolates and B. ribis $(99 \%)$ but did not strongly support the pistachio Fusicoccum isolates as a group distinct from $B$. ribis and $F$. luteum.

Conidium morphology. Lengths of conidia of the $B$. dothidea isolates tended to be greater (means of 26.7 to $30.0 \mu \mathrm{m}$ ) than those of the pistachio Fusicoccum isolates (means of 20.3 to $22.3 \mu \mathrm{m}$ ), B. ribis (18.9 $\mu \mathrm{m})$, and F. luteum (22.7 to $25.5 \mu \mathrm{m}$ ) (Table 2). Widths of the conidia of the $B$. dothidea isolates usually were less than those of the other fungi; therefore, ratios of length to width of the $B$. dothidea isolates (means of 4.2 to $5.0 \mu \mathrm{m}$ ) were greater than those of the pistachio Fusicoccum isolates, $B$. ribis, and F. luteum (means of 2.6 to 3.3 $\mu \mathrm{m})(P<0.05$; Table 2$)$. The shape of the conidia from the pistachio Fusicoccum isolates (Fig. 3C and D) also was more similar to the slightly ovoid to obovoid conidia of B. ribis (Fig. 3E) and F. luteum (Fig. 3F) than the fusiform conidia of $B$. dothidea (Fig. 3A and B).

\section{DISCUSSION}

Our results strongly support the conclusion that the pistachio Fusicoccum from California is not $B$. dothidea. RAPD marker analysis, ITS sequence analysis, and comparison of conidial morphology allow these fungi to be clearly differentiated. Recognition of this pistachio pathogen as distinct from $B$. dothidea has immediate implications for those involved in research concerning the serious disease it causes. For example, this distinction may explain the recently reported genetic dissimilarity between isolates of the pistachio Fusicoccum and putative B. dothidea isolates from other woody plant hosts in California (10). This finding also is of importance to further phylogenetic investigations of the genus Botryosphaeria and related anamorphic fungi.

Differences among RAPD markers and ITS sequences previously have been very useful for characterizing Botryosphaeria spp. and related anamorphic fungi. RAPD marker analyses allowed differentiation of discrete groups among fungi referred to as Sphaeropsis sapinea $(23,24)$. In addition, analysis of RAPD markers of Botryosphaeria spp. has facilitated meaningful selections of isolates for subsequent sequence analyses (21). Previous analyses of ITS sequences of Botryosphaeria spp. and related anamorphic fungi have indicated that differences of only a very few nucleotides are found between well-defined, accepted species $(7,9,32)$. Thus, the relatively large number of nucleotide differences in the ITS sequences of $B$. dothidea and the pistachio Fusicoccum very strongly support the distinction between them.

Confusion of the pistachio Fusicoccum with the anamorph of $B$. dothidea illustrates the problems with identification based on morphological and cultural comparison. Characteristics of fungi in this group are known to be influenced by substrates $(5,9,28)$. Jacobs and Rehner (9) noted that colony morphology among isolates of Botryosphaeria spp. "was the most variable character evaluated" and observed 12 distinct colony types among the eight species examined. Similarly, Pennycook 
and Samuels (14) had difficulty distinguishing $F$. luteum from $B$. dothidea on each of three common media. Finally, the size ranges of conidia of Botryosphaeria spp. and related anamorphic fungi have long been reported to overlap, and conidial color and septation may change with age $(5,14,18,19,25-27)$.

Despite these problems, conidial morphology recently was found to be useful in differentiating $B$. dothidea ( $F$. aesculi) from a complex consisting of fungi with Fusicoccum anamorphs (21). As in the current study, conidia of isolates of $B$. dothidea were distinctly fusiform and had greater length:width ratios than the conidia of $B$. ribis and $F$. luteum. The validity of

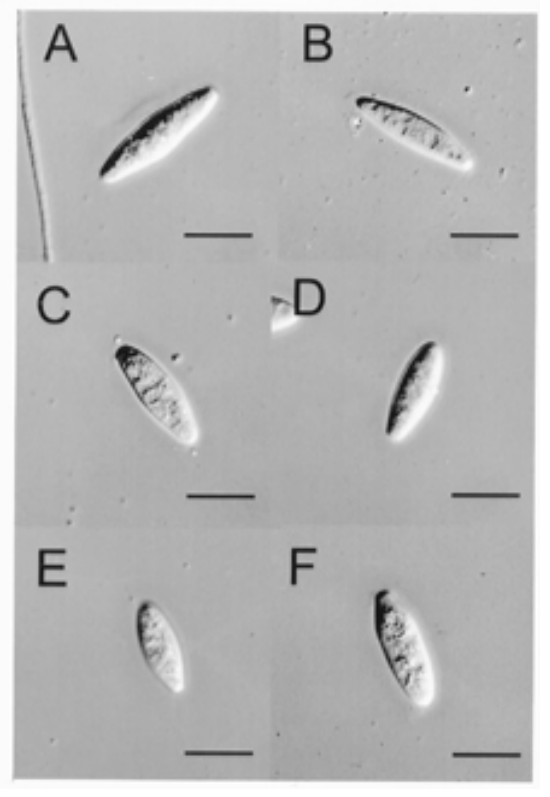

Fig. 3. Conidia of: Botryosphaeria dothidea isolates A, 96-6 and B, 97-5; pistachio Fusicoccum isolates C, 99-7 and D, 99-12; E, $B$. ribis isolate 94-131; and $\mathbf{F}, F$. luteum isolate 97-45. $\mathrm{Bar}=10 \mu \mathrm{m}$. this morphological distinction between conidia of $B$. dothidea and the pistachio Fusicoccum was strongly supported by the RAPD marker and ITS region sequence comparisons. Neither conidium morphology nor molecular markers, however, allowed clear differentiation of the pistachio Fusicoccum from isolates of $F$. luteum, a fungus reported from Australia and New Zealand, but also from pistachio in Italy (21). As suggested previously (21), more extensive research is necessary to clarify the status of taxa in this complex.

Differentiation of the pistachio Fusicoccum from $B$. dothidea should stimulate additional study. Different species of Botryosphaeria and related anamorphic fungi vary in many potentially important characteristics. For example, Pennycook and Samuels (14) found that F. luteum would not grow on benzimidazole-amended media, although $B$. dothidea was not inhibited, and Britton and Hendrix (3) found evidence that $B$. dothidea differs from $B$. obtusa and $B$. rhodina in its mode of infection of peach trees. Thus, further research should include well-characterized isolates of $B$. dothidea and other fungi with Fusicoccum anamorphs $(21,32)$. Results of comparative studies should clarify potential differences in host range and disease biology that may lead to more effective and efficient control and decrease losses in commercial pistachio production.

\section{ACKNOWLEDGMENTS}

We thank all those who collected or provided isolates, and P. S. McManus for presubmission review of the manuscript.

\section{LITERATURE CITED}

1. Arx, J. A. von, and Müller, E. 1954. Die Gattungen der amerosporen Pyrenomyceten. Beitr. Kryptogamenflora Schweiz 11:1-434.

2. Britton, K. O., and Hendrix, F. F. 1982. Three species of Botryosphaeria cause peach tree gummosis in Georgia. Plant Dis. 66:11201121.
3. Britton, K. O., and Hendrix, F. F. 1989. Infection of peach buds by Botryosphaeria obtusa. Plant Dis. 73:65-68.

4. Brown-Rytlewski, D. E., and McManus, P. S. 2000. Virulence of Botryosphaeria dothidea and Botryosphaeria obtusa on apple and management of stem cankers with fungicides. Plant Dis. 84:1031-1037.

5. Butin, H. 1993. Morphological adaptation and spore pleomorphism in the form-complex $\mathrm{Di}$ chomera-Camarosporium and FusicoccumDothiorella. Sydowia 45:161-166.

6. Crous, P. W., and Palm, M. E. 1999. Reassessment of the anamorph genera Botryodiplodia Dothiorella, and Fusicoccum. Sydowia 51:167-175.

7. Denman, S., Crous, P. W., Taylor, J. E., Kang, J-C., Pascoe, I., and Wingfield, M. J. 2000. An overview of the taxonomic history of Bot ryosphaeria, and a re-evaluation of its anamorphs based on morphology and ITS rDNA phylogeny. Stud. Mycol. 45:129-140.

8. English, H., Davis, J. R., and DeVay, J. E. 1975. Relationship of Botryosphaeria dothidea and Hendersonula toruloidea to a canker disease of almond. Phytopathology 65:114-122.

9. Jacobs, K. A., and Rehner, S. A. 1998. Comparison of cultural and morphological characters and ITS sequences in anamorphs of Botryosphaeria and related taxa. Mycologia 90:601-610.

10. Ma, Z., Boehm, E. W. A., Luo, Y., and Michailides, T. J. 2001. Population structure of Botryosphaeria dothidea from pistachio and other hosts in California. Phytopathology 91:665-672.

11. Ma, Z., Luo, Y., and Michailides, T. J. 2001. Resistance of Botryosphaeria dothidea from pistachio to iprodione. Plant Dis. 85:183-188.

12. Michailides, T. J. 1991. Pathogenicity, distribution, sources of inoculum, and infection courts of Botryosphaeria dothidea on pistachio. Phytopathology 81:566-573.

13. Michailides, T. J., Teviotdale, B. L., and Weinberger, G. 1999. Botryosphaeria Blight of Pistachio: Identification and Control Manual. California Pistachio Commission, Fresno.

14. Pennycook, S. R., and Samuels, G. J. 1985 Botryosphaeria and Fusicoccum species associated with ripe fruit rot of Actinidia deliciosa (kiwifruit) in New Zealand. Mycotaxon 24:445-458.

15. Punithalingam, E., and Holliday, P. 1973. Botryosphaeria ribis. Description of Patho-

Table 2. Conidial dimensions for isolates examined in an attempt to differentiate the pistachio Fusicoccum from other Fusicoccum and Botryosphaeria spp. ${ }^{\mathrm{x}}$

\begin{tabular}{|c|c|c|c|c|c|c|c|}
\hline \multirow[b]{2}{*}{ Species, isolate ${ }^{y}$} & \multirow[b]{2}{*}{ RAPD $^{z}$} & \multicolumn{2}{|c|}{ Conidial length $(\mu \mathrm{m})$} & \multicolumn{2}{|c|}{ Conidial width $(\mu \mathrm{m})$} & \multicolumn{2}{|c|}{ Length/width } \\
\hline & & Mean & Range & Mean & Range & Mean & Range \\
\hline \multicolumn{8}{|c|}{ Botryosphaeria dothidea } \\
\hline $96-6$ & $\mathrm{Bd}$ & $30.0 \mathrm{a}$ & $24-38$ & $7.2 \mathrm{~b}$ & $6-9$ & $4.2 \mathrm{c}$ & $3.3-6.3$ \\
\hline $97-114$ & $\mathrm{Bd}$ & $26.7 \mathrm{c}$ & $23-33$ & $6.3 \mathrm{~d}$ & $5-7.5$ & $4.3 \mathrm{c}$ & $3.4-5.8$ \\
\hline $97-5$ & $\mathrm{Bd}$ & $27.6 \mathrm{~b}$ & $22-35$ & $5.5 \mathrm{f}$ & $4.5-6.5$ & $5.0 \mathrm{a}$ & $3.7-6.5$ \\
\hline $96-14$ & $\mathrm{Bd}$ & $28.1 \mathrm{~b}$ & $23-37$ & $5.9 \mathrm{e}$ & $5-8.5$ & $4.8 \mathrm{~b}$ & $3.6-6.3$ \\
\hline \multicolumn{8}{|l|}{ B. ribis } \\
\hline $94-131$ & $\mathrm{Br}$ & $18.9 \mathrm{~h}$ & $16-23$ & $7.3 \mathrm{c}$ & $6-10$ & $2.6 \mathrm{~g}$ & $2.0-3.5$ \\
\hline \multicolumn{8}{|c|}{ Fusicoccum luteum } \\
\hline $96-130$ & $\mathrm{Fl}$ & $25.5 \mathrm{~d}$ & $21-30$ & $7.8 \mathrm{a}$ & $7-9$ & $3.3 \mathrm{~d}$ & $2.6-3.8$ \\
\hline $97-45$ & $\mathrm{Fl}$ & $22.7 \mathrm{e}$ & $19-25$ & $7.8 \mathrm{a}$ & $7-9$ & $2.9 \mathrm{f}$ & $2.2-3.6$ \\
\hline \multicolumn{8}{|c|}{ Pistachio Fusicoccum } \\
\hline $99-7$ & $\mathrm{Fp}$ & $20.3 \mathrm{~g}$ & $17-27$ & $6.8 \mathrm{c}$ & $5.5-8$ & 3.0 ef & $2.2-4.2$ \\
\hline $99-12$ & Fp & $21.3 \mathrm{f}$ & $17-27$ & $6.8 \mathrm{c}$ & $5.5-9$ & $3.1 \mathrm{de}$ & $2.5-4.4$ \\
\hline $99-13$ & Fp & $22.3 \mathrm{e}$ & $17-27$ & $7.4 \mathrm{~b}$ & $6-9$ & $3.0 \mathrm{ef}$ & 2.4-3.9 \\
\hline
\end{tabular}

${ }^{x}$ Sixty conidia per isolate were measured. Values (within columns) followed by the same letter were not significantly different at $P=0.05$ using Fisher's protected least significant difference.

${ }^{y}$ Species names are those used by collector/collection and are not necessarily indicative of identity.

${ }^{\mathrm{z}}$ Refers to group from results of random amplified polymorphic DNA (RAPD) marker analysis; $\mathrm{Bd}=$ Botryosphaeria dothidea, Br $=$ B. ribis, Fl = Fusicoccum luteum, and Fp = pistachio Fusicoccum . 
genic Fungi and Bacteria, No. 395. Commonwealth Mycological Institute, Kew, Surrey, UK.

16. Rayachhetry, M. B., Blakeslee, G. M., Webb, R. S., and Kimbrough, J. W. 1996. Characteristics of the Fusicoccum anamorph of Botryosphaeria ribis, a potential biological control agent for Melaleuca quinquenervia in south Florida. Mycologia 88:239-248.

17. Rice, R. E., Uyemoto, J. K., Ogawa, J. M., and Pemberton, W. M.. 1985. New findings on pistachio problems. Calif. Agric. 39:15-18.

18. Shear, C. L., Stevens, N. E., and Wilcox, M. S. 1925. Botryosphaeria and Physalospora in the eastern United States. Mycologia 17:98107.

19. Sivanesan, A. 1984. The Bitunicate Ascomycetes and Their Anamorphs. J. Cramer, Vaduz, Germany.

20. Smith, D. R., and Stanosz, G. R. 1995. Confirmation of two distinct populations of Sphaeropsis sapinea in the north central United States using RAPDs. Phytopathology 85:699-704

21. Smith, D. R., and Stanosz, G. R. 2001. Molecular and morphological differentiation of
Botryosphaeria dothidea (anamorph Fusicoccum aesculi) from some other fungi with Fusicoccum anamorphs. Mycologia 93:505515.

22. Sneath, P. H. A., and Sokal, R. R. 1973. Numerical Taxonomy. W. H. Freeman, San Francisco.

23. Stanosz, G. R., Swart, W. J., and Smith, D. R. 1998. Similarity between fungi identified as Diplodia pinea f. sp. cupressi in Israel and Botryosphaeria stevensii or Diplodia mutila on Juniperus in the United States. Eur. J. For. Pathol. 28:33-42.

24. Stanosz, G. R., Swart, W. J., and Smith, D. R. 1999. RAPD marker and isozyme characterization of Sphaeropsis sapinea from diverse coniferous hosts and locations. Mycol. Res. 103:1193-1202.

25. Stevens, N. E. 1926. Two species of Physalospora on citrus and other hosts. Mycologia 18:206-217.

26. Stevens, N. E. 1933. Two apple black rot fungi in the United States. Mycologia 25:536548.

27. Stevens, N. E., and Shear, C. L. 1929. Botryosphaeria and Physalospora in the Hawai- ian islands. Mycologia 21:313-320.

28. Sutton, B. C. 1980. The Coelomycetes. Commonwealth Mycological Institute, Kew, Surrey, UK.

29. Swofford, D. L. 2000. Phylogenetic Analysis Using Parsimony (* and Other Methods). Version 4.0b4a. Sinauer Associates, Sunderland, MA.

30. Thompson, J. D., Gibson, T. J., Plewniak, F. Jeanmougin, F., and Higgins, D. G. 1997. The ClustalX windows interface: flexible strategies for multiple sequence alignment aided by quality analysis tools. Nucleic Acid Res. 25:4876-4882.

31. White, T. J., Bruns, T., Lee, S., and Taylor, J. 1990. Amplification and direct sequencing of fungal ribosomal RNA genes for phylogenetics. Pages 315-322 in: PCR Protocols: A Guide to Methods and Applications. M. A Innis, D. H. Gelfand, J. J. Sninsky, and T. J. White, eds. Academic Press, San Diego, CA.

32. Zhou, S., and Stanosz, G. R. 2001. Relationships among Botryosphaeria species and associated anamorphic fungi inferred from the analyses of ITS and 5.8S rDNA sequences. Mycologia 93:516-527. 